\section{Total and Individual Glucosinolate Content in 11 Broccoli Cultivars Grown in Early and Late Seasons}

\author{
Eduardo A.S. Rosa ${ }^{1}$ and Ana S. Rodrigues \\ Field Crops Department, Universidade de Trás-os-Montes e Alto Douro, \\ Apartado 202, 5001-911 Vila Real codex, Portugal \\ Additional index words. Brassica oleracea, Italica Group, Brassicaceae, composition, \\ inflorescences
}

\begin{abstract}
Broccoli (Brassica oleracea L. Italica Group) is an economically important vegetable crop and its consumption may benefit human health. Glucosinolates, a group of secondary plant metabolites found generally in the cultivated Brassicaceae, may protect against the development of certain malignancies. The objective of this study was to evaluate total and individual glucosinolate content of broccoli cultivars widely grown in southern Europe following spring vs. summer planting (early vs. late crop, respectively). Glucosinolates in primary and secondary inflorescences taken from mature plants were analyzed separately by high performance liquid chromatography (HPLC). The cultivars contained primarily 4-methylsulfinylbutyl-, indol-3-ylmethyl- and 1-methoxyindol-3ylmethyl-glucosinolates. Total and individual glucosinolate levels varied significantly between seasons, among cultivars and between inflorescences. 'Shogun' contained the highest total glucosinolate levels (between $35.2 \mathrm{mmol} \cdot \mathrm{kg}^{-1}$ dry weight in primary inflorescences of the early crop and $\mathbf{4 7 . 9}$ in secondary inflorescences of the late crop). Total and individual glucosinolate levels were generally higher in the late than in the early crop. Primary inflorescences generally contained the highest glucosinolate levels in the early crop but secondary inflorescences had the highest levels in the late one.
\end{abstract}

Glucosinolates are a class of secondary plant metabolites found in dicots, particularly in the order Capparales, comprising the Capparaceae, Brassicaceae (Cruciferae), Koeberliniaceae, Moringaceae, Resedaceae and Tovariaceae (Rodman et al., 1998). Glucosinolates are particularly abundant in the Brassicaceae, an important group of cultivated plants in the world.

Intact glucosinolates feature a side chain (R) and a sulfur-linked D-glucopyranose moiety (Fig. 1). More than 100 glucosinolates have been isolated from various plant sources and they are characterized mainly by the Rgroup, which can be aromatic, indolic or aliphatic. Glucosinolates may be enzymatically hydrolyzed by the enzyme myrosinase (thioglucoside glucohydrolase, EC 3.2.3.1) to yield a variety of biologically-active products, including isothiocyanates, thiocyanates, nitriles, and oxazolidine-2-thiones. The nature of the original glucosinolates present in the plant and the conditions of enzymatic hydrolysis determine the types of compounds produced and their biological activities. Several studies have evaluated the glucosinolate composition of a range of cultivated Brassicas (see review by Rosa et al., 1997). Total and indi-

Received for publication 25 Oct. 1999. Accepted for publication 10 Apr. 2000. The cost of publishing this paper was defrayed in part by the payment of page charges. Under postal regulations, this paper therefore must be hereby marked advertisement solely to indicate this fact.

${ }^{1}$ To whom reprint requests should be addressed. E-mail address: erosa@utad.pt perishable vegetable, producers tend to grow suitable cultivars under mild climatic condi-

Fig. 1. General structure of intact glucosinolates. tions in spring and summer, principally for the fresh market, although some cultivars are more suited to freezing.

Under normal growing conditions, flower initiation in broccoli is accompanied by a gradual broadening of the apex where the primary inflorescence is inserted (Hadley and Pearson, 1999), and the formation of secondary inflorescences in the leaf axils. Although secondary inflorescences grow better after the primary inflorescence is harvested, they are smaller, representing $\approx 30 \%$ of the total yield (Rosa, unpublished).

In this study, we measured the glucosinolate content in 11 broccoli cultivars commonly grown in southern Europe ('Marathon' represents $\approx 60 \%$ of the production area), comparing early vs. late crop, for total and individual glucosinolate content, particularly those compounds thought to impart specific health benefits. To our knowledge, this is the first report describing glucosinolate levels in primary vs. secondary inflorescences, although Fahey and Stephenson (1999) have reported 4-methylsulfinylbutyl- and indol-3-ylmethylglucosinolate concentrations in two accessions of broccoli over a 2.5 -month period.

\section{Materials and Methods}

Plantmaterial. Seeds of 'Bejo', 'Claudia', 'Durango', 'Green Valiant', 'Legend', 'Marathon', 'Senshi', 'Shogun', 'SK ', 'SK ', and 'Tokyodome' were placed $2.5 \mathrm{~cm}$ deep in 45 $\mathrm{cm}^{3}$ cells in polypropylene trays filled with a mixture of 3 peat compost (Humobact Terreau, Frans Baele SA, France) : 1 river sand (v/v). Sowing dates were 1 Apr. 1997 for the early and 14 Aug. 1997 for the late crop. For both seasons, seedlings were transplanted 29 d after sowing, at the 4-5 true leaf stage, in an experimental field at the Univ. of Trás-osMontes e Alto Douro (lat. $41^{\circ} 17^{\prime} \mathrm{N}$, long. $7^{\circ} 44^{\prime} \mathrm{W}$, alt. $453 \mathrm{~m}$ ). The statistical design was a randomized complete block with three replicates of 21 plants each. For analysis, a total of five plants were randomly selected and used in each of the three replicates. Harvest of the early crop occurred between 52 and $70 \mathrm{~d}$ after planting for the primary inflorescences and between 64 and $84 \mathrm{~d}$ for the secondary inflorescences. Harvest of the late crop occurred between 67 and 94 d after planting for the primary inflorescences and between 117 and $131 \mathrm{~d}$ for the secondary

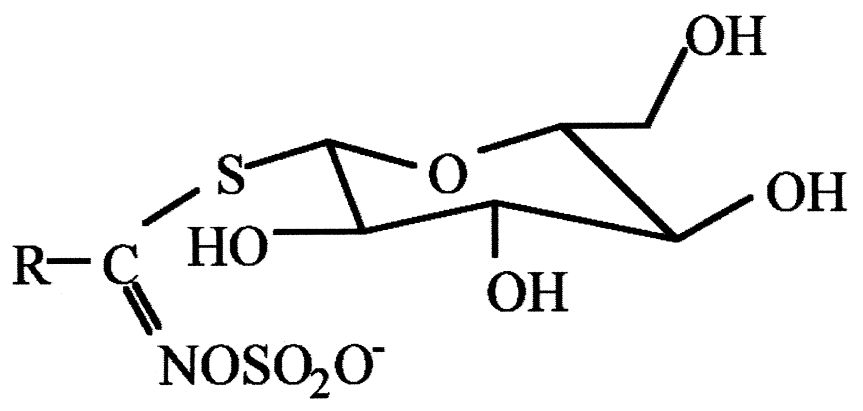


inflorescences. Inflorescences were always harvested at the same time of day to avoid environmental effects (Rosa, 1997). About half of the inflorescences of each replicate were then immediately freeze-dried and the other half were dried in a forced-air oven at $60{ }^{\circ} \mathrm{C}$ until constant weight to determine the dry weight. Glucosinolate analysis followed the procedure described by Rosa (1997), of which the main steps are as follows. A 0.2-g sample of freeze-dried and powdered inflorescences was extracted in $90 \%$ boiling methanol for 2 min using a small centrifuge tube, to which was added $0.2 \mathrm{~mL}$ of benzyl glucosinolate (glucotropaeolin) $\left(1 \mathrm{mg} \cdot \mathrm{mL}^{-1}\right)$ as an internal standard. After centrifugation, the supernatant was transferred to a 10 -mL flask. The residue was extracted twice in $70 \%$ boiling methanol for $1 \mathrm{~min}$, the solution was centrifuged each time and the supernatant was added to the same flask. The final volume was made to $10 \mathrm{~mL}$ with water. A 2.5 $\mathrm{mL}$ aliquot was evaporated to dryness and resuspended in a similar volume of pure water. A 2-mL aliquot was added to a small Sephadex A25 column and desulfoglucosinolates were obtained after treatment of the column with sulfatase (Sigma Chemical Co, St. Louis). A final volume of $1.5 \mathrm{~mL}$ was recovered for HPLC analysis, using a $5 \mu$ Spherisorb (Phase Separations, Deeside, UK) ODS2 $\mathrm{C}_{18}$ reverse-phase column $(250 \times 4.6$ $\mathrm{mm}$ ) with a mobile phase of water and acetonitrile $(20 \%)$ at a flow rate of $1.5 \mathrm{~mL} \cdot \mathrm{min}^{-1}$, according to the method described by Spinks et al. (1984). Individual glucosinolates were identified by comparison of retention times with those of known reference compounds and by adding separate, individual, pure compounds to broccoli extracts and observing the rise in peak height. Glucosinolate levels were expressed in mmol. $\mathrm{kg}^{-1} \mathrm{DW}$. For data analysis, analyses of variance (ANOVA) were performed using a SuperANOVA package (v. 1.11; Abacus Concepts, Berkeley, Calif.). When significant treatment differences occurred, the means were separated using the Student's $t$ test.

\section{Results and Discussion}

A typical glucosinolate chromatogram from broccoli inflorescences is presented in Fig. 2. The glucosinolate pattern of the cultivars was similar to that described by other authors (Hansen et al., 1995; Kushad et al., 1999; Lewis et al., 1991). The compounds 2-hydroxybut-3-enyl-, 4-methylsulfinylbutyl-, 5-methylsulfinylpentyl-, indol-3ylmethyl-, 2-phenylethyl-, 4-methoxyindol-3-ylmethyl, and 1-methoxyindol-3ylmethyl-glucosinolate were common to both inflorescences of all cultivars. Only 3methylsulfinylpropyl-glucosinolate could not be detected in 'Tokyodome' and in the secondary inflorescences of 'Bejo' and 'Senshi'. The but-3-enyl glucosinolate could not be detected only in the secondary inflorescences of 'Bejo' and ' $\mathrm{SK}_{4}$ '. No 2-hydroxy-2phenylethyl-glucosinolate was detected in the secondary inflorescences of 'Bejo', 'Claudia',

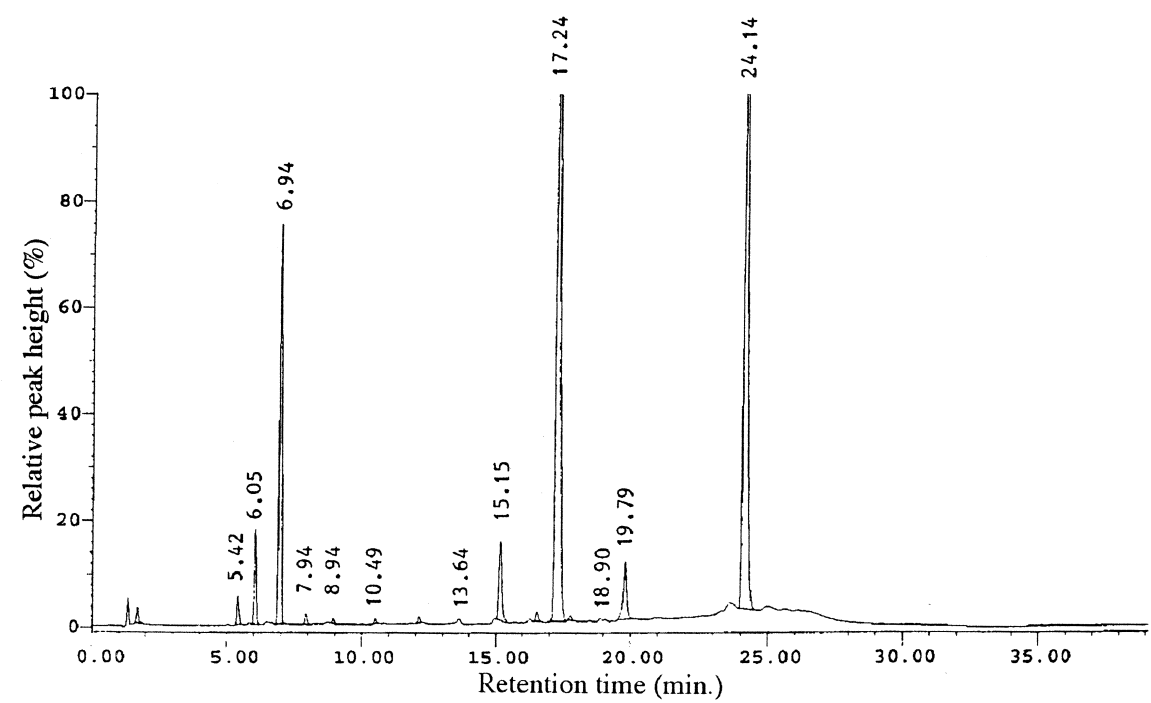

Fig. 2. Typical glucosinolate chromatogram from broccoli inflourescences. Glucosinolates and retention times (min): 3-methylsulfinylpropyl- (5.42); 2-hydroxybut-3-enyl- (6.05); 4-methylsulfinylbutyl- (6.94); 5-methylsulfinylpentyl- (7.94); but-3-enyl- (8.94); 4-hydroxyindol-3-ylmethyl- (10.49); 2-hydroxy-2phenylethyl- (13.64); benzyl- (15.15) (Internal Standard); indol-3-ylmethyl- (17.24); 2-phenylethyl(18.90); 4-methoxyindol-3-ylmethyl- (19.79); and 1-methoxyindol-3-ylmethyl- (24.14).
'Legend', 'Marathon', or 'Senshi', or in the primary inflorescences of ' $\mathrm{SK}_{4}$ '.

Individual glucosinolate levels generally differed with growing season except for 3methylsulfinylpropyl-, 5-methylsulfinylpentyland 4-hydroxyindol-3-ylmethyl- glucosinolates, and with inflorescences except for but-3-enyl- and 2-hydroxy-2-phenylethyl glucosinolates (Table 1). Cultivars, although having similar glucosinolate patterns, differed $(P \leq 0.001)$ in relative levels (Table 1$)$.

Total glucosinolates. Total glucosinolate levels were significantly $(P \leq 0.001)$ affected by season (S), inflorescence (I), and cultivar (C) (Table 1). All interactions were also significant except $\mathrm{I} \times \mathrm{C}$. On average, total glucosinolates were higher in both inflorescences in the late than in the early crops, which is consistent with the results of Schreiner et al. (1998) but not with those of Rosa et al. (1996). However, levels in each inflorescence varied with season (significant $\mathrm{S} \times \mathrm{I}$ interaction). In the late crop, levels in the secondary inflorescences (lower biomass) were higher than in primary inflorescences (higher biomass), indicating a "dilution" effect, as described in studies with cabbage (Brassica oleracea L. Capitata Group) (Pocock et al., 1987). Only two ('Bejo' and 'Durango') of the 11 cultivars contained higher total glucosinolate levels in secondary inflorescences of the early crop, because they were harvested in July with much higher temperatures (Table 2) than in June, when primary inflorescences were harvested. Since myrosinase activity in broccoli florets (an organ containing immature tissue that is actively growing at harvest) is the second highest within a wide range of Brassica species, and increases with temperature, particularly between 20 and $50{ }^{\circ} \mathrm{C}$ (Yen and Wei, 1993), the higher temperatures may have contributed to these differences by stimulating myrosinase activity, which would have degraded glucosinolates, thereby reducing their levels.

Glucosinolate levels are also reported to vary among cultivars (Rosa et al., 1997). In our studies, 'Shogun' had the highest glucosinolate levels $\left[59.3 \mathrm{mmol} \cdot \mathrm{kg}^{-1} \mathrm{DW}\right.$ in the secondary inflorescences of the late crop and $27.0 \mathrm{mmol} \cdot \mathrm{kg}^{-1} \mathrm{DW}$ in the primary inflorescences of the early crop (Table 3 )]. The
Table 1. Results of the analysis of variance for the total and individual glucosinolates in 11 cultivars of broccoli.

\begin{tabular}{|c|c|c|c|c|c|c|c|c|c|c|c|c|}
\hline \multirow{2}{*}{$\begin{array}{l}\text { Source of } \\
\text { variance }\end{array}$} & \multicolumn{12}{|c|}{ Glucosinolate $^{z}$} \\
\hline & 1 & 2 & 3 & 4 & 5 & 6 & 7 & 8 & 9 & 10 & 11 & Total \\
\hline Season $(\mathrm{S})$ & NS & $* * *$ & $* * *$ & NS & $* * *$ & NS & $* * *$ & $* * *$ & $* * *$ & $* * *$ & $* * *$ & $* * *$ \\
\hline Inflorescence (I) & $* * *$ & $* *$ & $* * *$ & $* * *$ & NS & $* * *$ & NS & $*$ & $* *$ & $* * *$ & $* * *$ & $* * *$ \\
\hline $\mathrm{S} \times \mathrm{I}$ & $* * *$ & $* * *$ & $* * *$ & NS & $*$ & $* * *$ & NS & $* *$ & NS & $* * *$ & $* *$ & $* * *$ \\
\hline Cultivar (C) & $* * *$ & $* * *$ & $* * *$ & $* * *$ & $* * *$ & $* * *$ & $* * *$ & $* * *$ & $* *$ & $* * *$ & $* * *$ & $* * *$ \\
\hline $\mathrm{S} \times \mathrm{C}$ & $* *$ & $* * *$ & $* * *$ & NS & $* * *$ & $* * *$ & $* * *$ & $* * *$ & $* *$ & $* *$ & $* * *$ & $* * *$ \\
\hline $\mathrm{I} \times \mathrm{C}$ & $* * *$ & $* * *$ & NS & NS & NS & $* * *$ & $* * *$ & NS & NS & $*$ & $* *$ & NS \\
\hline $\mathrm{S} \times \mathrm{I} \times \mathrm{C}$ & NS & $* * *$ & NS & $* *$ & NS & $* * *$ & $* * *$ & $* *$ & NS & $*$ & $* *$ & $*$ \\
\hline
\end{tabular}

" Glucosinolates: 1 = 3-methylsulfinylpropyl-; 2 = 2-hydroxybut-3-enyl-; 3 = 4-methylsulfinylbutyl-; 4 = 5-methylsulfinylpentyl-; 5 = but-3-enyl-; 6 = 4-hydroxyindol-3-ylmethyl-; 7 = 2-hydroxy-2-phenylethyl-; 8 = indol-3-ylmethyl-; 9 = 2-phenylethyl-; 10 = 4-methoxyindol-3-ylmethyl-; and 11 = 1-methoxyindol3-ylmethyl-.

Ns, ${ }^{*}, *, * * *$ Nonsignificant or significant at $P \leq 0.05,0.01,0.001$ by ANOVA. 
Table 2. Average maximum and minimum air temperatures, sunlight, and rainfall during early and late seasons of broccoli production.

\begin{tabular}{|c|c|c|c|c|}
\hline \multirow[b]{2}{*}{ Crop } & \multicolumn{2}{|c|}{ Avg air temp $\left({ }^{\circ} \mathrm{C}\right)$} & \multirow{2}{*}{$\frac{\text { Sunlight }}{\text { (h) }}$} & \multirow{2}{*}{$\begin{array}{r}\text { Rainfal } \\
\text { (mm) }\end{array}$} \\
\hline & Min & $\operatorname{Max}$ & & \\
\hline \multicolumn{5}{|c|}{ Early } \\
\hline May & 9.5 & 19.1 & 178.6 & 103.9 \\
\hline June & 10.6 & 20.7 & 208.4 & 62.0 \\
\hline July & 13.4 & 26.6 & 224.6 & 41.9 \\
\hline \multicolumn{5}{|c|}{ Late } \\
\hline September & 13.4 & 26.4 & 132.7 & 2.5 \\
\hline October & 11.4 & 21.2 & 161.0 & 131.6 \\
\hline November & 7.7 & 13.2 & 71.0 & 348.0 \\
\hline December & 4.5 & 10.8 & 70.3 & 227.7 \\
\hline January & 6.7 & 12.3 & 60.0 & 90.9 \\
\hline
\end{tabular}

lowest total glucosinolate levels (15.2 $\left.\mathrm{mmol} \cdot \mathrm{kg}^{-1} \mathrm{DW}\right)$ were observed in the secondary inflorescences of the early crop of ' $\mathrm{SK}_{4}$ ', (Table 3); however, on average, 'Tokyodome' had the lowest levels.

Harvest occurred 55-70 d and 74-90 d after planting in the early and late crops, respectively. No correlation $(r=0.407, P=$ 0.763 ) was found between total glucosinolates and length of growing season in the late crops, but in the early crops there was a negative correlation $(r=0.328, P=0.039)$. Although the latest cultivar ('Shogun') consistently had higher total glucosinolate levels, the earliest cultivar ('Claudia') also was among the cultivars with the highest total glucosinolate levels (Table 3). Thus in broccoli, the length of the growing season and glucosinolate levels appear to be unrelated.

Total glucosinolate levels were only $55 \%$ ('Marathon') of that reported by Hansen and coworkers (1995) but $71 \%$ higher ('Shogun') than the values reported by Kushad et al. (1999). They were 50\% higher than levels described by Carlson and coworkers (1987), who measured total glucosinolate by the glucose release method, twice as great as mean levels for 24 calabrese cultivars (Lewis and Fenwick, 1987), and within the levels found by Goodrich et al. (1989) and Lewis and coworkers (1991). For these comparisons we have chosen only glucosinolate levels from primary inflorescences in the early crop, since none of the above studies referred to second- ary or early crop inflorescences. If total glucosinolates from secondary inflorescences are considered, these are higher than any of the levels found in the above studies in which the same cultivar (Shogun) was used.

Inherent genetic differences among cultivars (including maturity) and climatic conditions during growth may explain the different levels of glucosinolates reported here. Since broccoli is highly perishable (Tian et al., 1997), time and postharvest climatic conditions occurring between harvest and sample preparation ( $<1 \mathrm{~h}$ in our study) could also account for such differences.

Individual glucosinolates. The major glucosinolate in these cultivars was 4-methylsulfinylbutyl-glucosinolate, representing between $55 \%$ ('Marathon' in the secondary inflorescences) and 23\% ('Claudia' in the primary inflorescences) of the total glucosinolate content in the late crop (data for minor individual glucosinolates may be obtained from authors upon request). This proportion dropped to a maximum of $46 \%$ ('Legend' in the primary inflorescences) and a minimum of $19 \%$ ('Durango' in the secondary inflorescences) in the early crop. These levels (Table 3 ) are similar to those reported by Fahey and coworkers (1997) for mature 'Saga' broccoli. Data reflect the main season (S) effect, due to differences in climatic conditions (Table 2), and their effect on inflorescences $(\mathrm{S} \times \mathrm{I})$, and cultivars $(\mathrm{S} \times \mathrm{C})$. Late crop resulted in higher

Table 3. Total and main individual glucosinolate levels $\left(\mathrm{mmol} \cdot \mathrm{kg}^{-1} \mathrm{DW}\right)$, in the primary $(\mathrm{P})$ and secondary $(\mathrm{S})$ inflorescences of the 11 cultivars of broccoli in early and late crops.

\begin{tabular}{|c|c|c|c|c|c|c|c|c|c|c|c|c|}
\hline \multirow[b]{2}{*}{ Crop } & \multicolumn{12}{|c|}{ Cultivar } \\
\hline & $\begin{array}{l}\text { Inflor- } \\
\text { escence }\end{array}$ & Bejo & Claudia & Durango & $\begin{array}{c}\text { Green } \\
\text { Valiant }\end{array}$ & Legend & Marathon & Senshi & Shogun & $\mathrm{SK}_{3}$ & $\mathrm{SK}_{4}$ & $\begin{array}{c}\text { Tokyo- } \\
\text { dome }\end{array}$ \\
\hline \multicolumn{13}{|c|}{ Total glucosinolates } \\
\hline \multirow[t]{2}{*}{ Early } & $\mathrm{P}$ & $15.9 \mathrm{aA}^{\mathrm{Z}}$ & $27.4 \mathrm{aB}$ & $19.5 \mathrm{aAC}$ & $25.2 \mathrm{aAB}$ & $21.8 \mathrm{aAB}$ & $20.8 \mathrm{aAB}$ & $21.9 \mathrm{aAB}$ & $35.2 \mathrm{acB}$ & $31.1 \mathrm{aBC}$ & $23.1 \mathrm{abAB}$ & $20.9 \mathrm{aAB}$ \\
\hline & $\mathrm{S}$ & $23.8 \mathrm{abA}$ & $24.2 \mathrm{aA}$ & $23.9 \mathrm{aA}$ & $24.9 \mathrm{aA}$ & $19.9 \mathrm{aA}$ & $20.1 \mathrm{aA}$ & $19.8 \mathrm{aA}$ & $27.0 \mathrm{cA}$ & $23.2 \mathrm{aA}$ & $15.2 \mathrm{aA}$ & $20.4 \mathrm{aA}$ \\
\hline \multirow[t]{2}{*}{ Late } & $\mathrm{P}$ & $23.5 \mathrm{abA}$ & $25.0 \mathrm{aA}$ & $15.5 \mathrm{aA}$ & $23.3 \mathrm{aA}$ & $23.7 \mathrm{aA}$ & $26.0 \mathrm{aA}$ & $24.6 \mathrm{aA}$ & $44.3 \mathrm{abB}$ & $27.7 \mathrm{aA}$ & $15.5 \mathrm{aA}$ & $21.5 \mathrm{aA}$ \\
\hline & $\mathrm{S}$ & $33.7 \mathrm{bACD}$ & $37.1 \mathrm{aAD}$ & $29.0 \mathrm{aAC}$ & $34.6 \mathrm{aACD}$ & $32.7 \mathrm{aAC}$ & $41.9 \mathrm{bAD}$ & $32.1 \mathrm{aAC}$ & $59.3 \mathrm{bBE}$ & $47.9 \mathrm{bDE}$ & $36.4 \mathrm{bACD}$ & $21.4 \mathrm{aC}$ \\
\hline \multicolumn{13}{|c|}{ 2-hydroxybut-3-enyl } \\
\hline \multirow[t]{2}{*}{ Early } & $\mathrm{P}$ & $0.1 \mathrm{aA}$ & $4.7 \mathrm{aB}$ & $0.1 \mathrm{aA}$ & $1.7 \mathrm{aA}$ & $0.3 \mathrm{aA}$ & $0.2 \mathrm{aA}$ & $0.2 \mathrm{aA}$ & $2.3 \mathrm{aAB}$ & $0.2 \mathrm{aA}$ & $1.7 \mathrm{aA}$ & $0.1 \mathrm{aA}$ \\
\hline & $\mathrm{S}$ & $0.2 \mathrm{aA}$ & $3.7 \mathrm{aB}$ & $0.2 \mathrm{aA}$ & $1.3 \mathrm{aAB}$ & $0.1 \mathrm{aA}$ & $0.1 \mathrm{aA}$ & $0.1 \mathrm{aA}$ & $1.1 \mathrm{aA}$ & $0.1 \mathrm{aA}$ & $0.2 \mathrm{aA}$ & $0.0 \mathrm{aA}$ \\
\hline \multirow[t]{2}{*}{ Late } & $\mathrm{P}$ & $0.1 \mathrm{aA}$ & $6.1 \mathrm{aBC}$ & $0.2 \mathrm{aA}$ & $4.3 \mathrm{bB}$ & $0.1 \mathrm{aA}$ & $0.1 \mathrm{aA}$ & $0.1 \mathrm{aA}$ & $7.4 \mathrm{bC}$ & $0.1 \mathrm{aA}$ & $0.1 \mathrm{aA}$ & $0.1 \mathrm{aA}$ \\
\hline & $\mathrm{S}$ & $0.1 \mathrm{aA}$ & $12.9 \mathrm{bB}$ & $0.0 \mathrm{aA}$ & $6.4 \mathrm{bAB}$ & $0.0 \mathrm{aA}$ & $1.0 \mathrm{aA}$ & $0.1 \mathrm{aA}$ & $11.2 \mathrm{cA}$ & $0.1 \mathrm{aA}$ & $0.1 \mathrm{aA}$ & $0.0 \mathrm{aA}$ \\
\hline \multicolumn{13}{|c|}{ 4-methylsulphinylbutyl } \\
\hline \multirow[t]{2}{*}{ Early } & $\mathrm{P}$ & $6.0 \mathrm{aA}$ & $8.1 \mathrm{aA}$ & $5.3 \mathrm{aA}$ & $7.4 \mathrm{aA}$ & $10.0 \mathrm{abA}$ & $8.5 \mathrm{aA}$ & $7.7 \mathrm{aA}$ & $9.5 \mathrm{aA}$ & $12.8 \mathrm{aA}$ & $7.0 \mathrm{abA}$ & $10.9 \mathrm{aA}$ \\
\hline & $\mathrm{S}$ & $5.0 \mathrm{aA}$ & $6.5 \mathrm{aA}$ & $4.4 \mathrm{aA}$ & $6.2 \mathrm{aA}$ & $6.3 \mathrm{aA}$ & $8.0 \mathrm{aA}$ & $6.8 \mathrm{aA}$ & $7.2 \mathrm{aA}$ & $10.2 \mathrm{aA}$ & $4.5 \mathrm{aA}$ & $7.3 \mathrm{aA}$ \\
\hline \multirow[t]{3}{*}{ Late } & $\mathrm{P}$ & $11.3 \mathrm{abAB}$ & $5.6 \mathrm{aA}$ & $6.7 \mathrm{aAB}$ & $10.9 \mathrm{abAB}$ & $10.1 \mathrm{abAB}$ & $14.1 \mathrm{aBC}$ & $11.2 \mathrm{abAB}$ & $20.6 \mathrm{bC}$ & $14.1 \mathrm{aBC}$ & $5.5 \mathrm{abA}$ & $6.8 \mathrm{aAB}$ \\
\hline & $\mathrm{S}$ & $16.2 \mathrm{bAB}$ & $8.7 \mathrm{aAD}$ & $11.7 \mathrm{aAD}$ & $15.5 \mathrm{bABD}$ & $15.6 \mathrm{bAB}$ & $23.0 \mathrm{bBC}$ & $17.1 \mathrm{bBE}$ & $28.5 \mathrm{bC}$ & $22.9 \mathrm{bBC}$ & $13.0 \mathrm{bADE}$ & $8.1 \mathrm{aD}$ \\
\hline & \multicolumn{12}{|c|}{ Indol-3-ylmethyl } \\
\hline \multirow[t]{2}{*}{ Early } & $\mathrm{P}$ & $5.1 \mathrm{aA}$ & $10.0 \mathrm{aB}$ & $4.1 \mathrm{aA}$ & $8.5 \mathrm{aAB}$ & $4.3 \mathrm{aA}$ & $5.5 \mathrm{aAB}$ & $4.8 \mathrm{aA}$ & $8.9 \mathrm{aAB}$ & $5.3 \mathrm{aAB}$ & $5.8 \mathrm{abAB}$ & $5.6 \mathrm{aAB}$ \\
\hline & $\mathrm{S}$ & $6.5 \mathrm{aABC}$ & $9.7 \mathrm{aB}$ & $5.7 \mathrm{aABC}$ & $8.8 \mathrm{aAB}$ & $4.3 \mathrm{aACD}$ & $5.2 \mathrm{aABC}$ & $4.7 \mathrm{aACD}$ & $5.4 \mathrm{aABC}$ & $3.9 \mathrm{aCD}$ & $2.3 \mathrm{aC}$ & $8.0 \mathrm{aBD}$ \\
\hline \multirow[t]{2}{*}{ Late } & $\mathrm{P}$ & $7.8 \mathrm{aA}$ & $8.5 \mathrm{aA}$ & $3.9 \mathrm{aA}$ & $4.3 \mathrm{aA}$ & $7.3 \mathrm{aA}$ & $5.3 \mathrm{aA}$ & $7.4 \mathrm{aA}$ & $7.9 \mathrm{aA}$ & $6.0 \mathrm{aA}$ & $4.1 \mathrm{aA}$ & $7.9 \mathrm{aA}$ \\
\hline & $\mathrm{S}$ & $9.8 \mathrm{aAB}$ & $9.6 \mathrm{aAB}$ & $8.0 \mathrm{aAB}$ & $5.4 \mathrm{aA}$ & $7.0 \mathrm{aAB}$ & $6.8 \mathrm{aAB}$ & $7.5 \mathrm{aAB}$ & $8.2 \mathrm{aAB}$ & $11.0 \mathrm{bB}$ & $9.9 \mathrm{bAB}$ & $6.1 \mathrm{aA}$ \\
\hline \multicolumn{13}{|c|}{ 4-methoxyindol-3-ylmethyl } \\
\hline \multirow[t]{2}{*}{ Early } & $\mathrm{P}$ & $0.7 \mathrm{aA}$ & $1.8 \mathrm{abAB}$ & $1.6 \mathrm{aA}$ & $1.7 \mathrm{aA}$ & $1.3 \mathrm{aA}$ & $0.9 \mathrm{aA}$ & $1.6 \mathrm{aA}$ & $2.3 \mathrm{abB}$ & $2.2 \mathrm{aA}$ & $1.5 \mathrm{aA}$ & $1.3 \mathrm{aA}$ \\
\hline & $\mathrm{S}$ & $1.8 \mathrm{abA}$ & $1.6 \mathrm{aA}$ & $2.1 \mathrm{aA}$ & $1.9 \mathrm{abA}$ & $1.5 \mathrm{aA}$ & $1.6 \mathrm{aA}$ & $1.8 \mathrm{aA}$ & $2.1 \mathrm{aA}$ & $1.8 \mathrm{aA}$ & $1.3 \mathrm{aA}$ & $1.8 \mathrm{aA}$ \\
\hline \multirow[t]{2}{*}{ Late } & $\mathrm{P}$ & $2.2 \mathrm{abA}$ & $3.3 \mathrm{bcAB}$ & $2.4 \mathrm{abAB}$ & $2.1 \mathrm{abA}$ & $3.1 \mathrm{bAB}$ & $3.2 \mathrm{bAB}$ & $2.7 \mathrm{aAB}$ & $3.7 \mathrm{bAB}$ & $3.0 \mathrm{aAB}$ & $2.2 \mathrm{aAB}$ & $3.8 \mathrm{bB}$ \\
\hline & $\mathrm{S}$ & $2.9 \mathrm{bA}$ & $3.7 \mathrm{cAB}$ & $4.3 \mathrm{bAB}$ & $3.4 \mathrm{bAC}$ & $3.3 \mathrm{bAC}$ & $4.9 \mathrm{cB}$ & $2.9 \mathrm{aA}$ & $3.5 \mathrm{abAB}$ & $5.0 \mathrm{bB}$ & $4.6 \mathrm{bBC}$ & $3.8 \mathrm{bAB}$ \\
\hline \multicolumn{13}{|c|}{ 1-methoxyindol-3-ylmethyl } \\
\hline \multirow[t]{2}{*}{ Early } & $\mathrm{P}$ & $3.5 \mathrm{aAC}$ & $1.4 \mathrm{aA}$ & $6.9 \mathrm{acBC}$ & $4.7 \mathrm{abAC}$ & 5.5abACD & $4.6 \mathrm{aAC}$ & $7.2 \mathrm{aBC}$ & $10.9 \mathrm{aB}$ & $9.3 \mathrm{aBD}$ & $5.3 \mathrm{abACD}$ & $2.5 \mathrm{aA}$ \\
\hline & $\mathrm{S}$ & $10.0 \mathrm{bA}$ & $1.1 \mathrm{aB}$ & $10.0 \mathrm{aA}$ & $5.5 \mathrm{bCD}$ & $7.3 \mathrm{bAD}$ & $3.4 \mathrm{aBCD}$ & $6.1 \mathrm{abAC}$ & $9.8 \mathrm{aAE}$ & $5.6 \mathrm{abCDE}$ & $5.0 \mathrm{abBCD}$ & $2.9 \mathrm{aBC}$ \\
\hline \multirow[t]{2}{*}{ Late } & $\mathrm{P}$ & $1.5 \mathrm{aA}$ & $0.4 \mathrm{aA}$ & $0.8 \mathrm{bA}$ & $0.6 \mathrm{aA}$ & $2.8 \mathrm{aA}$ & $1.4 \mathrm{aA}$ & $2.7 \mathrm{bA}$ & $3.0 \mathrm{bA}$ & $2.9 \mathrm{bA}$ & $1.9 \mathrm{aA}$ & $2.6 \mathrm{aA}$ \\
\hline & $\mathrm{S}$ & $4.2 \mathrm{aAB}$ & $0.5 \mathrm{aA}$ & $3.3 \mathrm{bcAB}$ & $1.9 \mathrm{abAC}$ & $6.2 \mathrm{abBD}$ & $3.7 \mathrm{aAD}$ & $4.2 \mathrm{abAD}$ & $5.3 \mathrm{bBCD}$ & $6.8 \mathrm{abBD}$ & $6.2 \mathrm{bBD}$ & $2.9 \mathrm{aAD}$ \\
\hline
\end{tabular}

${ }^{\mathrm{z}}$ Mean separation within columns and glucosinolates (lower case letters) for comparisons between seasons and inflorescences and within rows for comparisons among cultivars (upper case letters), by Student's $t$ test, $P \leq 0.001$. 
4-methylsulfinylbutyl-glucosinolate levels in all cultivars except 'Tokyodome', with 'Shogun' having the highest level (Table 3). The levels were almost twice those reported by Fahey et al. (1997). However, in the early crop, levels in the secondary inflorescences were lower than those in the primary ones, showing a significant $\mathrm{S} \times \mathrm{I}$ interaction (Table 1). The lowest 4-methylsulfinylbutyl glucosinolate concentration in the secondary inflorescences was almost 10 times that reported by Fahey and Stephenson (1999) for two prolific lateral-shooting broccoli cultivars, also examined over a long period ( $>2$ months). The 4-methylsulfinylbutyl-glucosinolate is considered to be an exceptional inducer of enzymes that protect against cancer, and the level found in this study was one-fourth of that recorded by Fahey et al. (1997) in 3-day-old broccoli sprouts. Although mature broccoli has lower levels of 4-methylsulfinylbutylglucosinolate, it may contain higher levels of other beneficial constituents (Nestle, 1997).

The indole group of glucosinolates is the most important, representing between 29\% (secondary inflorescences of 'Shogun' in the late crop) and $74 \%$ (secondary inflorescences of 'Durango' in the early crop) of the total glucosinolate content. The two major glucosinolates in the indole group are indol-3ylmethyl- and 1-methoxyindol-3-ylmethylglucosinolates, as found in other studies (Hansen et al., 1995; Kushad et al., 1999). The other indole glucosinolate was 4-methoxyindol-3-ylmethyl-glucosinolate, which represented a minimum of $5 \%$ (primary inflorescences of 'Bejo') and a maximum of 9\% (secondary inflorescences of 'Durango'), both in the early crop. In the late crop the proportions were slightly higher, varying between $6 \%$ (secondary inflorescences of 'Shogun') and $18 \%$ (primary inflorescences of 'Tokyodome').

The proportion of indol-3-ylmethyl- and 1methoxyindol-3-ylmethyl- glucosinolates showed a large variation between cultivars (C), which performed differently according to season $(\mathrm{S} \times \mathrm{C})$ (Table 3$)$. 'Claudia' was the cultivar with the highest proportion of indol3 -ylmethyl glucosinolate, $38 \%$ and $30 \%$ in the early and late crops, respectively, while in ' $\mathrm{SK}_{3}$ ' indol-3-ylmethyl glucosinolate represented only $17 \%$ and $23 \%$, respectively. An inverse relation was noted for these two cultivars in the proportion of 1-methoxyindol-3ylmethyl-glucosinolate. On average (11 cultivars), early planting induced a similar percentage of both indole glucosinolates, $26 \%$ and $23 \%$, respectively, in indol-3-ylmethyl- and 1-methoxyindol-3-ylmethyl-glucosinolate, while late planting caused a large variation, with $26 \%$ and $10 \%$, respectively. Although the average (11 cultivars) level of indol-3ylmethyl-glucosinolate was between $50 \%$ and $75 \%$ of the level reported by Fahey et al. (1997) for 'Saga', levels in the secondary inflorescences of some cultivars ('Bejo', 'Claudia', ' $\mathrm{SK}_{3}$ ', and ' $\mathrm{SK}_{4}$ ') in the late crop were similar. Although levels of 1-methoxyindol-3-ylmethyl-glucosinolate were closer to values reported by Fahey et al. (1997), levels in secondary inflorescences were higher.

Considering the potential beneficial effects to human health of 4-methylsulfinylbutylisothiocyanate and derivatives from the indole glucosinolates (Beecher, 1994; Cover et al., 1998; Zhang et al., 1992), broccoli is a vegetable of high dietary value. Some cultivars may be more beneficial than others. Although broccoli might be grown year-round, late planting seems to result in higher glucosinolate levels. Based on this study, extending the growing season to harvest secondary inflorescences with higher levels of the precursors of well-recognized beneficial compounds would be worthwhile. This study also confirms the large variation in glucosinolate levels among broccoli cultivars and identifies a group of cultivars (including 'Shogun') that contain high levels.

\section{Literature Cited}

Beecher, C.W.W. 1994. Cancer preventive properties of varieties of Brassica oleracea: A review. Amer. J. Clin. Nutr. 59(suppl):1166S-1170S.

Carlson, D.J., M.E Daxenbichler, C.H. VanEtten, W.F. Kwolek, and P.H. Williams. 1987. Glucosinolates in crucifer vegetables: Broccoli, brussels sprouts, cauliflower, collards, kale, mustard greens, and kohlrabi. J. Amer. Soc. Hort. Sci. 112:173-178

Cover, C.M., S.J. Hsieh, S.H. Tran, G. Hallden, G.S Kim, L.F. Bjeldanes, and G.L. Firestone. 1998. Indole-3-carbinol inhibits the expression of cyclin-dependent kinase- 6 and induces a G1 cell cycle arrest of human breast cancer cells independent of estrogen receptor signaling. J. Biol. Chem. 273:3838-3847.

Fahey, J.W. and K.K. Stephenson. 1999. Cancer chemoprotective effects of cruciferous vegetables. HortScience 34:1159-1163.

Fahey, J.W., Y. Zhang, and P. Talalay. 1997. Broccoli sprouts: An exceptionally rich source of inducers of enzymes that protect against chemical carcinogens. Proc. Natl. Acad. Sci. 94:1036710372.

Goodrich, R.M., J.L. Anderson, and G.S. Stoewsand 1989. Glucosinolate changes in blanched broccoli and brussels sprouts. J. Food Proc. Preserv. $13: 275-280$

Hadley, P. and S. Pearson. 1999. Physiology, p. 359-373. In: C. Gómez Campo (ed.). Biology of Brassica Coenospecies. Elsevier, Amsterdam.

Hansen, M., P. Møller, H. Sørensen, and M.C. de Trejo. 1995. Glucosinolates in broccoli stored under controlled atmosphere. J. Amer. Soc. Hort. Sci. 120:1069-1074.
Kushad, M.M., A.F. Brown, A.C.Kurilich, J.A. Juvik, B.P. Klein, M.A. Wallig, and E.H. Jeffery. 1999. Variation of glucosinolates in vegetable subspecies of Brassica oleracea. J. Agr. Food Chem. 47:1541-1548

Lewis, J.A., G.R. Fenwick, and A.R. Gray. 1991. Glucosinolates in Brassica vegetables: Greencurded cauliflowers (Brassica oleracea L. botrytis group) and purple-headed broccoli ( $B$. oleracea L. italica group). Lebensm.-Wiss. U.Technol., 24:361-363.

Lewis, J.A. and G.R. Fenwick. 1987. Glucosinolate content of Brassica vegetables: Analysis of twenty four cultivars of calabrese (green sprouting broccoli, Brassica oleracea L. var botrytis subvar. Cymosa Lam.). Food Chem. 25:259268

Nestle, M. 1997. Broccoli sprouts as inducers of carcinogen-detoxifying enzyme systems: Clinical, dietary, and policy implications. Proc. Natl. Acad. Sci. 94:11149-11151.

Pocock, K., R.K. Heaney, A. Wilkinson, J.E. Beaumont, J.G. Vaughan, and G.R. Fenwick. 1987. Changes in myrosinase activity and isoenzyme pattern, glucosinolate content and the cytology of myrosinase cells in the leaves of heads of three cultivars of English white cabbage. J. Sci. Food Agr. 41:245-257.

Rodman, J.E., P.S. Soltis, D.E. Soltis, K.J. Sytsma, and K.G. Karol. 1998. Parallel evolution of glucosinolate biosynthesis inferred from congruent nuclear and plastid gene phylogenies. Amer. J. Bot. 85:997-1006.

Rosa, E.A.S. 1997. Daily variation in glucosinolate concentrations in the leaves and roots of cabbage seedlings in two constant temperature regimes. J. Sci. Food Agr. 73:364-368.

Rosa, E.A.S., R.K Heaney, G.R. Fenwick, and C. Portas. 1997. Glucosinolates in crop plants. Hort. Rev. 19:99-215.

Rosa, E., R.K. Heaney, C.A.M. Portas, and G.R. Fenwick. 1996. Changes in glucosinolate concentrations in Brassica crops (B. oleracea and B. napus) throughout growing seasons. J. Sci. Food Agr. 71:237-244.

Schreiner, M., I. Schonhof, and A. Krumbein. 1998. New dimension in product quality-Bioactive substances in vegetables. Gemuse-Munchen 34:82-84.

Spinks, A., K. Sones, and G.R. Fenwick. 1984 The quantitative analysis of glucosinolates in cruciferous vegetables, oilseeds and forage crops using high performance liquid chromatography. Fette Seifen Anstrichmittel 86:228-231.

Tian, M.S., T. Islam, D.G. Stevenson, and D.E. Irving. 1997. Color, ethylene production, respiration, and compositional changes in broccoli dipped in hot water. J. Amer. Soc. Hort. Sci. 122:112-116

Yen, G.-C. and Q.-K. Wei. 1993. Myrosinase activity and total glucosinolate content of cruciferous vegetables, and some properties of cabbage myrosinase in Taiwan. J. Sci. Food Agr. 61:471475 .

Zhang, Y., P. Talalay, C.-G. Cho, and G.H. Posner. 1992. A major inducer of anticarcinogenic protective enzymes from broccoli: Isolation and elucidation of structure. Proc. Natl. Acad. Sci. (USA) 89:2399-2403. 